\title{
The Effect Of Addition Of Polypropylene Fibers On Crushed Glass Concrete Mixed
}

\author{
Albert Aun Umbu Nday*, Theresia Avila Bria, Deasi D. A. A. Daud \\ \{albertaun.umbunday@gmail.com*,thessa_bria@yahoo.co.id, deasi.daud@gmail.com\} \\ Politeknik Negeri Kupang, Jl. Adisucipto Penfui-Kupang-NTT
}

\begin{abstract}
The solution of environmental problems with a lot of indutrial and household waste by recycling waste such as rubber tires, glass fragments, tile fragments, ceramic fragments and fly-ash. This study aims develop new innovation of concrete mixing using household waste by substituted $15 \%$ glass crushed of the total weight of fine aggregate to polypropylene fibers concrete to get compressive strength. The result showed that BK and $\mathrm{BS}$ have a higher compressive strength than $\mathrm{BN}$ with the precentage increase of $13.82 \%$ and $18.53 \%$ at day 28 . This study become a solution of waste problems by utilizing glass waste as an alternative to added concrete is very effectively.
\end{abstract}

Keywords: polypropylene fibers; crushed glass; concrete mixed

\section{Introduction}

The solution of environmental problems with a lot of indutrial and household waste are a challenge to solved it. Green construction is a hot issue for the last recently years. Green construction as a result from Green materials thereof recycling of industrial and household waste as a solution for it. Indutrial and household waste such as rubber tires, glass fragments, tile fragments, ceramic fragments, fly-ash, etc. This research used recycling materials is crushed glass with addition polypropylene fibers in concrete mixing. This study aims develop new innovation of concrete mixing using household waste. The development of concrete fibers is progressing and is proven to be able to improve the performance of concrete such as CFRP [1], Polypropylene and etc. In previous studies glass concrete mix with substitution in fine aggregate of $15 \%$ was able to increase the strength of concrete compared to normal concrete [2], [3], [4]. However, the use of crushed glass of more than $20 \%$ can reduce the strength of concrete and used crushed glass can make concrete works easily [5]. Polypropylene fibers can be found on everyday necessities where they are made of plastic [6]. Concrete with a mixture of Polypropylene fibers can increase the compressive strength of concrete [7].

\section{Materials and method}

\subsection{Speciments and materials}

The speciments are used in this study are concrete cyllinders with addition crushed glass and polypropylene fibers. 


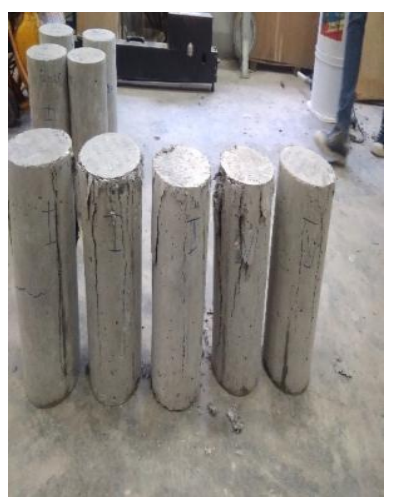

Cyllinders Speciments

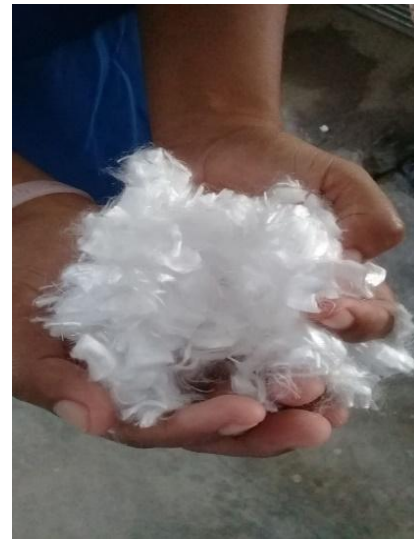

(a)

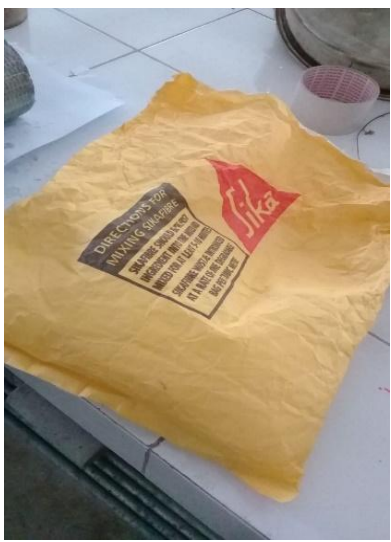

(b)

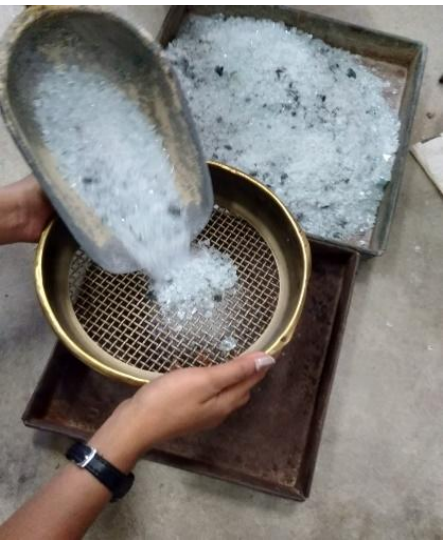

(c)

Figure 1. Polypropylene fibers (a,b) and crushed glass (c)

This study uses glass has become a waste. The glass is fine crushed based the requirements of passing the fine aggregate with granules between $0.15 \mathrm{~mm}$ and $5 \mathrm{~mm}$. Then the crushed glass is substituted by $15 \%$ of the total weight of fine aggregate. The concrete mix design is 30 $\mathrm{MPa}$. The polypropylene fibers used are already in the marketplace is SIKA fibre. Terms of use of SIKA fiber in concrete is 600 grams / m3. The amount of polypropylene fibers recommended by most manufacturers for use in paving mixtures and most other mixtures is 0.1 percent by volume of concrete ( 0.889 to $0.949 \mathrm{~kg}$ per cubic meter) [8]. SIKA fiber used is in proportion to the volume of concrete. Speciments category consists of normal concrete (BN) with 9 specimens, concrete mixture of $15 \%$ glass (BK) with 9 specimens, concrete mix glass of $15 \%$ + polypropylene fiber (BS) with 9 specimens. For all specimens tested based on the characteristics of concrete age on day 7 , day 14 and day 28. Furthermore, comparing the compressive strength of concrete based on the characteristics of the constituent concrete material and the age of the concrete.

\subsection{Method}

Speciments was tested on Universal Testing Machine (UTM) to get compression strength and the setting up showed at Figure 2. 


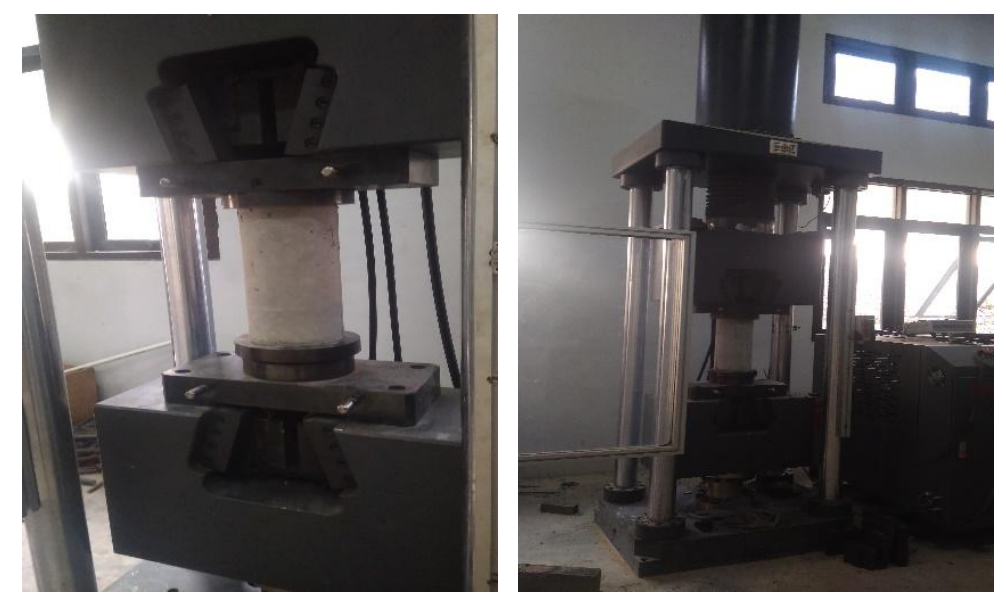

Figure 2. Setting up cyllinders compression test

\section{Results and discussion}

\subsection{Result test of normal concrete compression strength (BN)}

Comparing result of normal concrete compression strength $(B N)$ for day 7, day 14, and day 28 at Table 1,2 , and 3 .

Table 1. Normal concrete compression strength (BN) for day 7

\begin{tabular}{cccc}
\hline $\begin{array}{c}\text { No. } \\
\text { Sample }\end{array}$ & $\begin{array}{c}\text { diameter } \\
(\mathrm{mm})\end{array}$ & $\begin{array}{c}\text { Area } \\
\left(\mathrm{mm}^{2}\right)\end{array}$ & $\begin{array}{c}\text { Compression } \\
\text { Strength }\left(f_{c}{ }^{\prime}\right) \\
(\mathrm{MPa})\end{array}$ \\
\hline BN1 & 150 & 17662.5 & 18.31 \\
\hline BN2 & 150 & 17662.5 & 18.02 \\
\hline BN3 & 150 & 17662.5 & 18.22 \\
\hline Average & & & 18.18 \\
\hline
\end{tabular}

Table 2. Normal concrete compression strength (BN) for day 14

\begin{tabular}{cccc}
\hline $\begin{array}{c}\text { No. } \\
\text { Sample }\end{array}$ & $\begin{array}{c}\text { diameter } \\
(\mathrm{mm})\end{array}$ & $\begin{array}{c}\text { Area } \\
\left(\mathrm{mm}^{2}\right)\end{array}$ & $\begin{array}{c}\text { Compression } \\
\text { Strength }\left(f_{c^{\prime}}\right) \\
(\mathrm{MPa})\end{array}$ \\
\hline BN4 & 150 & 17662.5 & 22.43 \\
\hline BN5 & 150 & 17662.5 & 22.34 \\
\hline BN6 & 150 & 17662.5 & 23.12 \\
\hline Average & & & 22.63 \\
\hline
\end{tabular}


Table 3. Normal concrete compression strength (BN) for day 28

\begin{tabular}{cccc}
\hline $\begin{array}{c}\text { No. } \\
\text { Sample }\end{array}$ & $\begin{array}{c}\text { diameter } \\
(\mathrm{mm})\end{array}$ & $\begin{array}{c}\text { Area } \\
\left(\mathrm{mm}^{2}\right)\end{array}$ & $\begin{array}{c}\text { Compression } \\
\text { Strength }\left(f c^{\prime}\right) \\
(\mathrm{MPa})\end{array}$ \\
\hline BN7 & 150 & 17662.5 & 28.05 \\
\hline BN8 & 150 & 17662.5 & 28.19 \\
\hline BN9 & 150 & 17662.5 & 29.71 \\
\hline Average & & & 28.65 \\
\hline
\end{tabular}

From Tables 1,2 and 3, it showed that the average compressive strength of BN for day 7 is $18.18 \mathrm{MPa}$, the average compressive strength of $\mathrm{BN}$ age of 14 days is $22.63 \mathrm{MPa}$, and the average BN compressive strength of day 28 is $28.65 \mathrm{MPa}$. The increasing percentage compressive strength of concrete age of 7 days to 14 days is $24.47 \%$ and the increasing percentage compressive strength of concrete age of 14 days to 28 days is $26.60 \%$. Compression Strength of Normally cyllinders has increase from 7 days, 14 days and the maximum strength at 28 days is $28.65 \mathrm{MPa}$. It described that the compression strength test moving as like as age of the cyllinders.

\subsection{Result test concrete mixture of $15 \%$ glass (BK)}

Comparing result of concrete mixture of $15 \%$ glass $(B K)$ for day 7 , day 14, and day 28 at Table 4,5, and 6.

Table 4. concrete mixture of $15 \%$ glass $(B K)$ for day 7

\begin{tabular}{cccc}
\hline $\begin{array}{c}\text { No. } \\
\text { Sample }\end{array}$ & $\begin{array}{c}\text { diameter } \\
(\mathrm{mm})\end{array}$ & $\begin{array}{c}\text { Area } \\
\left(\mathrm{mm}^{2}\right)\end{array}$ & $\begin{array}{c}\text { Compression } \\
\text { Strength }\left(f c^{\prime}\right) \\
(\mathrm{MPa})\end{array}$ \\
\hline BK4 & 150 & 17662.5 & 24.37 \\
\hline BK5 & 150 & 17662.5 & 23.20 \\
\hline BK6 & 150 & 17662.5 & 24.96 \\
\hline Average & & & 24.17 \\
\hline
\end{tabular}

Table 5. concrete mixture of $15 \%$ glass $(B K)$ for day 14

\begin{tabular}{cccc}
\hline $\begin{array}{c}\text { No. } \\
\text { Sample }\end{array}$ & $\begin{array}{c}\text { diameter } \\
(\mathrm{mm})\end{array}$ & $\begin{array}{c}\text { Area } \\
\left(\mathrm{mm}^{2}\right)\end{array}$ & $\begin{array}{c}\text { Compression } \\
\text { Strength }\left(f_{c^{\prime}}\right) \\
(\mathrm{MPa})\end{array}$ \\
\hline BK4 & 150 & 17662.5 & 26.61 \\
\hline BK5 & 150 & 17662.5 & 26.88 \\
\hline BK6 & 150 & 17662.5 & 20.91 \\
\hline Average & & & 24.80 \\
\hline
\end{tabular}


Table 6. concrete mixture of $15 \%$ glass $(B K)$ for day 28

\begin{tabular}{cccc}
\hline $\begin{array}{c}\text { No. } \\
\text { Sample }\end{array}$ & $\begin{array}{c}\text { diameter } \\
(\mathrm{mm})\end{array}$ & $\begin{array}{c}\text { Area } \\
\left(\mathrm{mm}^{2}\right)\end{array}$ & $\begin{array}{c}\text { Compression Strength }\left(f c^{\prime}\right) \\
(\mathrm{MPa})\end{array}$ \\
\hline BK4 & 150 & 17662.5 & 31.89 \\
\hline BK5 & 150 & 17662.5 & 32.42 \\
\hline BK6 & 150 & 17662.5 & 33.53 \\
\hline Average & & & 32.61 \\
\hline
\end{tabular}

From Tables 4,5 and 6, it showed that the average compressive strength of BK for day is 24.17 $\mathrm{MPa}$, the average compressive strength of BK for day 14 is $24.80 \mathrm{MPa}$, and the average compressive strength of BK for day 28 is $32.61 \mathrm{MPa}$. The percentage of the increasing strength in compressive strength of the concrete age of 7 days to 14 days is $2.61 \%$ and the percentage of the increasing strength in compressive strength of the concrete age of 14 days to 28 days is $31.49 \%$. From these results provide an explanation that the increasing strength of compressive strength of concrete at the age of 7 days to 14 days is not as strentgh as the compressive strength of concrete 14 days to 28 days.

\subsection{Result test concrete mix glass of $15 \%+$ polypropylene fiber (BS)}

Comparing result of concrete mixture of $15 \%$ glass $(B K)$ for day 7 , day 14 , and day 28 at Table 7,8, and 9 .

Table 7. concrete mix glass of $15 \%$ + polypropylene fiber (BS) for day 7

\begin{tabular}{cccc}
\hline $\begin{array}{c}\text { No. } \\
\text { Sample }\end{array}$ & $\begin{array}{c}\text { diameter } \\
(\mathrm{mm})\end{array}$ & $\begin{array}{c}\text { Area } \\
\left(\mathrm{mm}^{2}\right)\end{array}$ & $\begin{array}{c}\text { Compression Strength }\left(f c^{\prime}\right) \\
(\mathrm{MPa})\end{array}$ \\
\hline BS1 & 150 & 17662.5 & 28.06 \\
\hline BS2 & 150 & 17662.5 & 27.39 \\
\hline BS3 & 150 & 17662.5 & 22.58 \\
\hline Average & & & 26.01 \\
\hline
\end{tabular}

Table 8. concrete mix glass of $15 \%+$ polypropylene fiber (BS) for day 14

\begin{tabular}{cccc}
\hline $\begin{array}{c}\text { No. } \\
\text { Sample }\end{array}$ & $\begin{array}{c}\text { diameter } \\
(\mathrm{mm})\end{array}$ & $\begin{array}{c}\text { Area } \\
\left(\mathrm{mm}^{2}\right)\end{array}$ & $\begin{array}{c}\text { Compression Strength }\left(f c^{\prime}\right) \\
(\mathrm{MPa})\end{array}$ \\
\hline BS1 & 150 & 17662.5 & 27.97 \\
\hline BS2 & 150 & 17662.5 & 31.07 \\
\hline BS3 & 150 & 17662.5 & 29.12 \\
\hline Average & & & 29.38 \\
\hline
\end{tabular}

Table 9. concrete mix glass of $15 \%$ + polypropylene fiber (BS) for day 28

No. diameter Area Compression Strength $\left(f c^{\prime}\right)$

\begin{tabular}{cccc} 
Sample & $(\mathrm{mm})$ & $\left(\mathrm{mm}^{2}\right)$ & $(\mathrm{MPa})$ \\
\hline BS1 & 150 & 17662.5 & 35.65 \\
\hline BS2 & 150 & 17662.5 & 33.95 \\
\hline BS3 & 150 & 17662.5 & 32.28 \\
\hline Average & & & 33.96 \\
\hline
\end{tabular}

From Tables 4,5 and 6, it showed that the average compressive strength of BS for 7 days is 26.01 $\mathrm{MPa}$, the average compressive strength of $\mathrm{BS}$ day 14 is $29.38 \mathrm{MPa}$, and the average 
compressive strength of BS day 28 is $3.61 \mathrm{MPa}$. The percentage of the increasing strength in compressive strength of the concrete age of 7 days to 14 days is $12.95 \%$ and the The percentage of the increasing strength in compressive strength of the concrete age of 14 days to 28 days is $15.58 \%$.

\subsection{Disscusion}

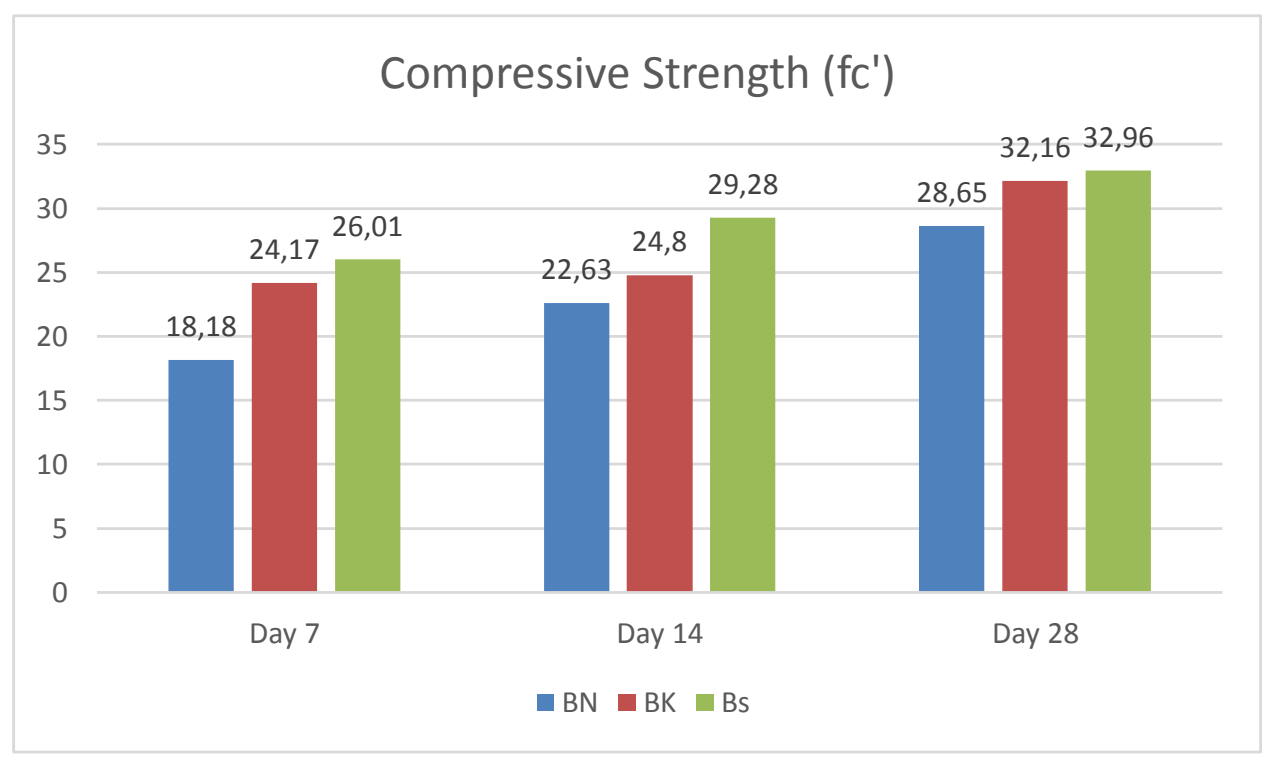

Figure 4. compressive strength chart

Based on figure 4 comparison of the compressive strength of day 7 concrete for $\mathrm{BN}$ is 18.18 $\mathrm{MPa}, \mathrm{BK}$ is $24.17 \mathrm{MPa}$, and $\mathrm{BS}$ is $26.01 \mathrm{MPa}$. It shows that BK and BS have higher compressive strength than $\mathrm{BN}$ with the percentage increase of $32.94 \%$ and $43.07 \%$. Furthermore, the compressive strength of day 14 for $\mathrm{BN}$ is $22.63 \mathrm{MPa}, \mathrm{BK}$ is $24.80 \mathrm{MPa}$, and $\mathrm{BS}$ is $29.38 \mathrm{MPa}$. It shows that BK and BS have a higher compressive strength than BN with the presentage increase of $9.59 \%$ and $29.83 \%$. And finally the compressive strength day 28 for $\mathrm{BN}$ is $28.65 \mathrm{MPa}, \mathrm{BK}$ is $32.61 \mathrm{MPa}$, and $\mathrm{BS}$ is $33.96 \mathrm{MPa}$. It shows that $\mathrm{BK}$ and $\mathrm{BS}$ have a higher compressive strength than BN with the precentage increase of $13.82 \%$ and $18.53 \%$. The compressive strength of BK and BS is higher than normal concrete due to reduced sand by $15 \%$ which is likely that the sand still has mud content. This causes the strength of concrete to increase due to glass crushed and polypropylene fibers able to work well as fillers in concrete mixtures. 


\section{Conclusion}

The results of the study concluded that BK and BS have higher compressive strength compared to BN, with an increase percentage of $13.82 \%$ and $18.53 \%$. This study become a solution of waste problems by utilizing glass waste as an alternative to added concrete is very effectively.

\section{References}

[1] Nday, A. A. U., Johannis, D. E . W., 2018 proceedings $1^{\text {st }}$ conference on computer science and engineering technology (ICCSET) universitas muria kudus

[2] Ikhsan, M.N., Prayuda, H., Saleh, F., 2016 Jurnal Ilmiah Semesta Teknika. Vol 19. No. 2, pp. $148-156$

[3] Indriani, L, 2016 Jurnal Rab Construction Research. Vol.1 No. 2, pp. 86-95

[4] Purnomo, H., Hisyam, E. S, 2014 Jurnal Fropil. Vol. 2. No. 1, pp. 45-55

[5] Kuruppu, G., Chandratilake, R., 2012 world construction conference, pp. 221-228

[6] Balaguru, P.N., Shah, S.P. 1992. Fiber Reinforced Cement Composites, McGraw-Hill International Edition, Singapore

[7] Gunawan, P., Wibowo., Suryawan N., 2014 e-Jurnal Matriks Teknik Sipil. Vol. 2. No. 2, pp. 206-213

[8] Mohod, M. V., 2015 IOSR Journal of Mechanical and Civil Engineering. Vol. 12, Issue 1 ver. 1 (Jan-Feb. 2015), pp. 28-36 